\title{
Reconfirmed occurrance and northward expansion of the royal flagfish Aulopus filamentosus (Bloch, 1792) from the Aegean Sea
}

\section{Aulopus filamentosus türünün Ege Denizi'nden yeniden onaylanmış gözlemi ve en kuzey dağılımı}

\author{
İsmail Burak Daban ${ }^{*}$ (D) • Kamil Çakır ${ }^{1}$ • Deniz Acarlı² • Ali İşmen ${ }^{1}$ \\ ${ }^{1}$ Department of Fisheries and Fish Processing, Faculty of Marine Science and Technology, Çanakkale Onsekiz Mart University, Çanakkale - Turkey \\ 2 Department of Fisheries Technology, Gökçeada School of Applied Sciences, Çanakkale Onsekiz Mart University, Gökçeada-Çanakkale, Turkey \\ *Corresponding author: burakdaban@comu.edu.tr
}

Received date: 11.04.2017 Accepted date: 15.06 .2017

How to cite this paper:

Daban, İ.B., Çakır, K., Acarlı, D. \& İşmen, A. (2017). Reconfirmed occurrance and northward expansion of the royal flagfish Aulopus filamentosus (Bloch, 1792) from the Aegean Sea. Ege Journal of Fisheries and Aquatic Sciences, 34(3): 337-339. doi:10.12714/egejfas.2017.34.3.13

\begin{abstract}
A single male specimen of the royal flagfin (Aulopus filamentosus), $369 \mathrm{~mm}$ total length was caught with the longline from the Gökçeada Island, north Aegean Sea. This report constitutes the reconfirmed occurrance with gives precise locality information from the Turkish waters and this record reflects northernmost expansion of this species in the Aegean Sea.
\end{abstract}

Keywords: Aulopus filamentosus, male, expansion, Aegean Sea

Öz: Kuzey Ege Denizi Gökçeada'da paragat ile 369 mm toplam boya sahip bir adet erkek Aulopus filamentosus bireyi yakalanmıştır. Bu kayıt Türkiye suları için türün kesin lokalite bilgisini içeren yeniden onaylanmış gözlemidir ve türün Ege Denizi için en kuzey dağılımını göstermektedir.

\section{INTRODUCTION}

The family Aulopidae has 12 species in all around the world whereas a great majority of these species are originated from South Western Pasific and some of them are endemic for Australia. Aulopidae is represented by single species with Aulopus filamentosus in the Mediterranean Sea. A. filamentosus is distributed in the eastern Atlantic from Canary Islands to Senegal, western central Atlantic from Gulf of Mexico to Caribbean and also distributed in the Mediterranean (Robins et al., 1991). It is marine demersal fish species and distributed at $50-1000 \mathrm{~m}$ (Sanches, 1991) depth interval but generally found at $100-200 \mathrm{~m}$ (Sulak, 1990). Data on biology of the species are very rare. Feeding type consist of mainly animals as cephalopods, finfish and benthic crustacea (Costa, 1991). Isometric growth type (b: 3.099; r2: 0.99) was reported from south east part of the Aegean Sea that known single weightlength relationship study (Yapıcı et al., 2015). This paper presents the northern expansion of this species in the Aegean Sea, which is the reconfirmed occurrance of the royal flagfin fish for the Turkish waters.

\section{MATERIALS AND METHODS}

A single specimen of $A$. filamentosus was caught on 4 February 2017 by fishermen. It was caught by longline with 9 no fishhook baited with Sephia officinalis at $150 \mathrm{~m}$ depth in the Northwestern part of the Gökçeada Island (lat $40^{\circ} 9^{\prime} 16^{\prime \prime} \mathrm{N}$, long $25^{\circ} 36^{\prime} 19^{\prime \prime}$ E) (Fig. 1).

The specimen was identified according to Mater et al. (2009). It was photographed, some morphometric characters measured and meristic characters were counted. The specimen was then fixed and preserved in $5 \%$ formalin solution. The single specimen was deposited in the Piri Reis Marine Museum of Çanakkale Onsekiz Mart University, Çanakkale, Turkey (PRM - PIS 2017-007) (Fig. 2).

\section{RESULTS}

Some morphometric measurements and meristic counts of the individual are given in Table 1. The specimen has relatively high head length, eye diameter and snout length. Dorsal fin origin is located behind the pelvic fin insertion. First ray of the 
dorsal fin stretched and extend over the dorsal fin insertion. Pectoral fin base reach up to third dorsal fin ray. Lateral line go along nearly straight and has 50 ctenoid scales. Adipose fin present that located last quarter of the total length. The sex of the individual was male whereas no remarkable spermatozoa on the testes. However elongated first dorsal fin ray reflects the sex toward male. The stomach of the specimen was emty.

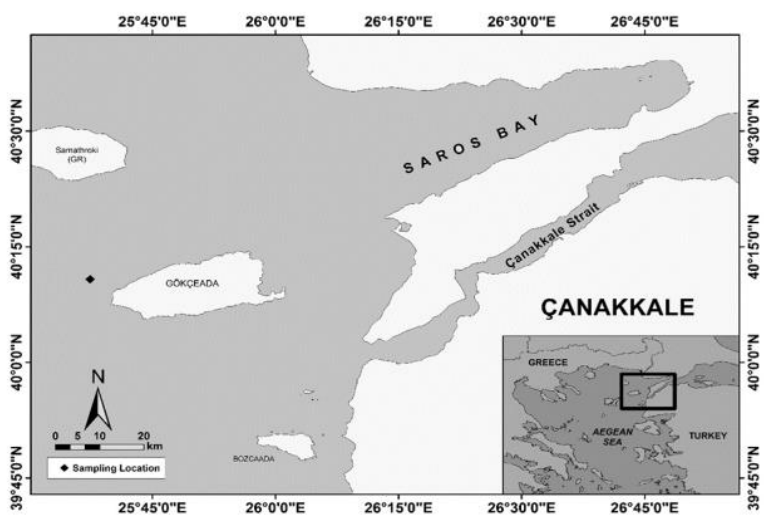

Figure 1. Sampling point (Black rhombus) of Aulopus filamentosus and general view of the Northern Aegean coasts of Turkey

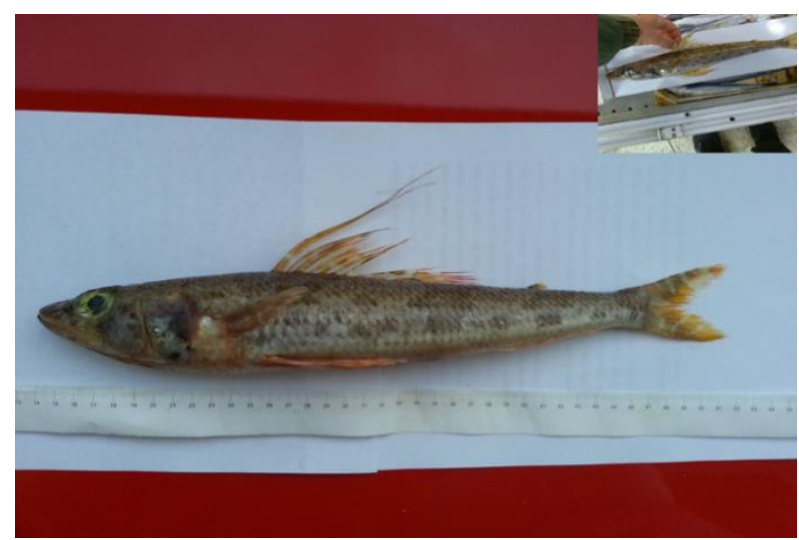

Figure 2. Royal flagfish Aulopus filamentosus and its first dorsal fin ray, which reflects sex of the individual

Table 1. Morphometric measurements and meristic counts of the single specimen of Aulopus filamentosus (Bloch, 1792) captured from the Gökçeada Island, Northern Aegean Sea (Turkey)

\begin{tabular}{lll}
\hline Morphometric measurements & mm & \multicolumn{1}{c}{ TL\% } \\
\hline Total length & 369 & 100 \\
Fork length & 341 & 92.4 \\
Standard length & 323 & 87.5 \\
Head length & 68 & 18.4 \\
Interorbital width & 24 & 6.5 \\
Body width & 46 & 12.5 \\
Body height & 56 & 15.2 \\
Snout length & 28 & 7.6 \\
Eye diameter & 21 & 5.7 \\
Pre - pectoral length & 98 & 26.6 \\
Pre - dorsal length & 118 & 32
\end{tabular}

\begin{tabular}{llc}
\hline Pre - anal length & 240 & 65 \\
Pre - pelvic length & 125 & 33.9 \\
Pre - adipose length & 259 & 70.2 \\
Pre - anüs length & 215 & 58.3 \\
Mouth height & 31 & 8.4 \\
Total mass (g) & 440 \\
\hline Meristic counts & \\
\hline Dorsal fin rays & 15 \\
Pectoral fin rays & 12 \\
Pelvic fin rays & 9 \\
Anal fin rays & \multicolumn{2}{c}{11} \\
Caudal fin rays & 19 \\
Lateral line scale & 50 \\
\hline
\end{tabular}

\section{DISCUSSION}

A. filamentosus has been reported by various researchers in the Mediterranean, Aegean and Adriatic Sea (Faber, 1883; Akşıray, 1954; Akyüz, 1957; Geldiay, 1969; Whitehead et al., 1984; Fischer et al., 1987; El Sayed, 1994; Al Hassan and ElSilini, 1999; Mater and Meriç, 1996; Mater and Bilecenoğlu, 1999; Bilecenoğlu et al., 2002) but provided no precise locality information and were presented in check list studies. Considering that precise locality information, this species was reported by Dulcic (2006) from the Adriatic Sea (Molunat Bay) and by Ben Souissiet al. (2010) from the northeastern Tunisia.

As for Turkish waters, only report based upon precise locality information was observed by Işmen et al. (2006) from the Aegean Sea (Babakale Harbour). In current study, the record of $A$. filamentosus from the Gökçeada Island demonstrated that northernmost extension range in the Aegean Sea. In addition, this is the first male individual compared with the other records which gives information about biology or locality. In accordance of fishermen observations in the area, A. filamentosus is quite rare species and one fishermen notified that he was firstly seen this species 4 years ago. Beside, informed that they have not seen any individual which was captured by bottom trawls up to day, encountered individuals were captured only by longlines. Cengiz et al. (2011) reported that 96 teleost fish species belonging to 43 families were identified from the Saros Bay, North Aegean Sea. However $A$. filamentosus was not sampled in that study. When considered that it was firstly reported 11 years ago from the Aegean Sea, the biomass and occurrance of the species has not been increased. Conversely, the biomass of the species has been rised in the southernmost of the Aegean Sea due to the study conducted by Yapıcı et al. (2015). They were presented weightlength relationship of the species for the first time with 11 individual from the samples taken from the bottom trowl. Changes of physico-chemical parameters in seawater may affect the physiology and distribution ranges of fishes, due to changes in prey abundance and distribution (Papaconstantinou, 2014). Southern part of the Aegean Sea has more temperate, saline and deeper waters than northern part of the Aegean Sea. This situation may provide more suitable biotope for $A$. filamentosus. However $A$. filamentosus 
has not been reported yet in the Marmara Sea and Black Sea from the Turkey. In these areas has less temperate, saline and shallower waters. Possible reports from these areas may help us to understand the biological requirements in deal with more northernmost expansion.

\section{REFERENCES}

Akşıray, F. (1954). A key to marine fishes of Turkey. Istanbul University Faculty of Science Hydrobiology Research Institute Publications, Istanbul, Turkey, $277 \mathrm{pp}$.

Akyüz, E. (1957). Observations on the Iskenderun red mullet (Mullus barbatus) and its environment. GFCM Proceedings and Techical Papers, 4(38): 305 326.

Al-Hassan, L.A.J. \& El-Silini, O.A. (1999). Checklist of bony fishes collected from the Mediterranean coast of Bengazi, Libya. Revista de Biologia Marina y Oceanografía, 34(2): 291-301.

Ben Souissi, S.J., Ben Amor, M.M. \& Capape, C. (2010). Confirmed occurrance of the royal flagfish, Aulopus filamentosus (Osteichthyes: Aulopidae) in Tunisian waters. Pan-American Journal of Aquatic Sciences, 5(1): 157 161.

Bilecenoğlu, M., Taşkavak, E., Mater, S. \& Kaya, M. (2002). Checklist of the marine fishes of Turkey. Zootaxa, 113(1): 1-194. doi:10.11646/zootaxa.113.1.1

Cengiz, Ö., İşmen, A., Özekinci, U. \& Öztekin, A. (2011). An Investigation on Fish Fauna of Saros Bay (Northern Aegean Sea). AKU-J. Sci., 11(011003): 31-37.

Costa, F. (1991). Atlante dei pesci dei mari italiani. Gruppo Ugo Mursia Editore S.p.A. Milano, Italy. 438 p.

Dulcic, J. (2006). On the record of he royal flagfin, Aulopus filamentosus (Pisces: Aulopidae), from the Adriatic Sea. Annales, series Historia Naturalis, 16(2): 189-192.

El Sayed, R.S. (1994). Check-list of Egyptian Mediterranean fishes. Institute of Oceanography and Fisheries. Alexandria, Egypt: ix + 77 pp.

Faber, G.L. (1883). The fisheries of the Adriatic and the fish thereof. A Reprt of the Austro - Hungarian sea - fisheries, with a detailed description of the Marine Fauna of the Adriativ Gulf. B. Quatrich, London, 178 pp.

Fischer, W., Bauchot, M.L. \& Schneider, M. (1987). Fiches FAO díidentification des espèces pour les besoins de la pêche. Mèditerranèe et mer Noire Zone de pêche 37. FAO and EEC, Rome, 761-1530.

\section{ACKNOWLEDGMENT}

We would like to thank the fishermen Mr. Bülent SÖNMEZ, Ali GÜNGÖR and Gazanfer INCE for fishing and providing the specimen of Aulopus filamentosus.

Geldiay, R. (1969). Important fishes found in the Bay of İzmir and their possible invasions. Ege University Faculty of Science Monographies, Izmir, Turkey, 135 pp. (In Turkish).

İşmen, A., Yığın, Ç. \& Çakır, F. (2006). A new fish species for the Northern Aegean Sea Fauna; Aulopus filamentosus (Bloch, 1792). E.U. Journal of Fisheries\&Aquatic Sciences, 23, Supp.1/1: 95-97.

Mater, S. \& Meriç, N. (1996). Marine fishes. In: Kence A, Bilgin CC (Eds), Turkey Vertebrata Species List, Nurol Press A.S., Ankara, 129-172. [in Turkish].

Mater, S. \& Bilecenoğlu, M. (1999). Marine fishes of Turkey. In: Demirsoy, A. (Ed), General Zoogeography and Zoogeography of Turkey [in Turkish], Meteksan Press, Ankara, 790-808.

Mater, S., Kaya, M. \& Bilecenoğlu, M. (2009). Marine fishes of Turkey (4th edn), Ege University Fisheries Faculty Publishings, İzmir, No. 68. (In Turkish).

Papaconstantinou, C. (2014). Fauna Graeciae. An updated checklist of the fishes in the Hellenic Seas. Monographs on Marine Sciences, 7, Athens 2014, HCMR, 340 p.

Robins, C.R., Bailey, R.M., Bond, C.E., Brooker, J.R., Lachner, E.A., Lea, R.N. \& Scott, W.B. (1991). Common and scientific names of fishes from the United States and Canada. Am. Fish. Soc. Spec. Pub., 20: 183 p.

Sanches, J.G. (1991). Catálogo dos principais peixes marinhos da República de Guiné-Bissau. Publ. Avuls. Inst. Nac. Invest. Pescas, 16: 429 p.

Sulak, K.J. (1990). Aulopidae. p. 349-350. In Quero J.C., Hureau J.C., Karrer C., Post A., Saldanha L. (eds.) Check-list of the fishes of the eastern tropical Atlantic (CLOFETA). JNICT, Lisbon; SEI, Paris; and UNESCO, Paris. Vol. 1.

Yapıcı, S., Karachle, P.K. \& Filiz, H. (2015). First length-weight relationships of 11 fish species in the Aegean Sea. Journal of Applied Ichthyology, 31(2): 398-402. doi:10.1111/jai.12459

Whitehead, P.J.P., Bauchot, M.L., Hureu, J.C., Nielsen, J. \& Tortonese, E. (eds) (1984-1986). Fishes of the North-eastern Atlantic and the Mediterranean, UNESCO, Paris, $1473 \mathrm{pp}$. 